Fighting for Indigenous Lands in Modern Brazil.

The reframing of cultures and identities

\title{
Indigenous Activism, Territorialization and Ethnicity in the Middle Rio Negro
}

Sidnei Clemente Peres'

'Instituto de Ciências Humanas e Filosofia, Departamento de Sociologia, Universidade Federal Fluminense, Niterói/RJ, Brasil

\begin{abstract}
This paper addresses the processes of territorialization, formation of indigenous associations and ethnogenesis in the Middle Rio Negro that have led to the most recent struggles for official recognition of indigenous lands. The central focus of description and analysis is the antagonism between the aviamento regime and the "community" as modalities of natural resource consumption and strategies for social reproduction. In the Upper Rio Negro, in the mid-1980s, at the heart of a process of inversion of ethnic stigma, crisis of missionary tutelage and developmentalist militarization; the community became the territorial base for political codification of the emerging formation of associations. At the beginning of the 21st century, indigenous associations gained new life in the Middle Rio Negro, clashing with the aviamento regime and intensifying the fight for territorial rights.
\end{abstract}

Keywords: Ethnicity, State, Amazon, Indigenous Peoples. 


\section{Ativismo Indígena, Territorialização e Etnicidade no Médio Rio Negro}

\section{Resumo}

Este artigo aborda os processos de territorialização, etnicidade e associativismo no Médio Rio Negro que desembocarão nas lutas mais recentes pelo reconhecimento oficial de terras indígenas. O eixo central da descrição e análise é o antagonismo entre o regime de aviamento e a "comunidade" enquanto modalidades de uso dos recursos naturais e estratégias de reprodução social. No Alto Rio Negro, em meados dos anos 1980 no cerne de um processo de inversão do estigma étnico, crise da tutela missionária e militarização desenvolvimentista; a comunidade se torna a base territorial de codificação política do associativismo emergente. No início do século XXI, o associativismo toma novo fôlego no Médio Rio Negro, colidindo com $\mathrm{o}$ aviamento e incrementando a luta por direitos territoriais.

Palavras-Chave: Etnicidade, Estado, Amazônia, Povos Indígenas. 


\title{
Indigenous Activism, Territorialization and Ethnicity in the Middle Rio Negro
}

\author{
Sidnei Clemente Peres
}

\section{Introduction}

Between the malocas ${ }^{1}$ of the Upper Rio Negro and the city of Manaus, in the 1950s, anthropologist Eduardo Galvão envisioned the formation of a mestizo and cabocla ${ }^{2}$ society, with the concomitant rise of a regional ethos. The result of this process of cultural change was a tendency towards assimilation - the complete cultural fusion of the Indians ${ }^{3}$ to Brazilian society, which could only be delayed or interrupted by modifying the orientation of the pioneering front of colonization that would drive the region's urbanization and industrialization. These conditions accentuated processes of discrimination and ethnic and social cleavages. The main factor of accommodation of the indigenous groups to cabocla society in formation was the extractive economy that isolated indigenous families in small rural settlements leaving them subordinated existence to the non-indigenous population, instead of "resulting in a retraction of the remaining tribal population to the malocas, in an 'indigenous reservation' type system" (Galvão 1979:186-187). In this social topology of stagnation and backwardness, this type of cabocla assimilation was expressed by the "sítio" (small rural plots of land) in contrast to the "maloca" and the "city", which are anthropologically characterized as original cultural impulses disrupted by the expansion of extractive activities that impeded a modernizing acculturation.

Three decades later, a process of ethnogenesis and indigenous activism has developed through the formation of indigenous associations on the Upper Rio Negro that expanded to the Middle Rio Negro in the following decade. Territorial rights made concrete in a mosaic of indigenous lands and an indigenous movement closely linked to international cooperation and to a global environmentalist public sphere would question this anthropology of modernization (or better, of the regional impediments to modernization) on the Rio Negro.

The idea of a folk-urban continuum, represented by the maloca (a metonymic sign of the "tribal") and by the "city" (a metonymic sign of the "civilized") as two extreme poles, is not foreign to the schemes of intelligibility subjacent to the public discourse and action of missionaries, indigenous activists, the military and other state agents in the Rio Negro basin. The concentration of the presence of missionary centers, non-governmental and governmental organizations on the Upper Rio Negro, in comparison to the Middle Rio Negro, is one of the forms of expression of this imaginary topology of acculturation in which going up or down the Rio Negro corresponds to entering or leaving civilization. Therefore, this imaginary topology must be considered as an element that is relevant to the anthropological understanding of the genesis of a social space of indigenous militancy on the Rio Negro, considered as a semantic field

\footnotetext{
1 Malocas are large communal houses where several domestic groups lived, constituting a modality of social organization of the indigenous settlements in the Amazon Northwest that succumbed to the fierce combat promoted by the Salesian missionaries.

2 Caboclo designates a condition or status resulting from cultural contact between indigenous and non-indigenous individuals or groups.

3 "Many among those who trace their roots to the Aboriginal peoples of the Americas prefer American Indians to Native Americans, and in certain historical works Indians may be more appropriate. Canadians often speak of First Peoples (and of First Nations) when not referring to specific groups by name.” (http:/ www.chicagomanualofstyle.org/book/ed17/part2/cho8/pseco38.html)
} 
of redefinition of meanings and experiences that originated from other social configurations such as the Salesian missionary centers and the aviamento regime ${ }^{4}$. Therefore, this imaginary topology must be denaturalized (by a historic anthropology) and explained as part of a web of practices and representations; and not naively considered and transformed into part of the analytical arsenal of the research without consideration.

We propose to understand the Middle Rio Negro based on the aviamento system, which is a social configuration that serves as a gateway to comprehending a social totality constructed by anthropological reflection in models that are never definitive; taking this compulsory form of recruitment and exploitation of work and control and use of natural resources, based on a notion of debt that transcends its economic dimensions. Aviamento is seen as a principle of constitution of a network of interdependence between individuals and groups; systems of positions and dispositions, ties of strength and meaning subjacent to the categories of patrão $0^{5}$ and freguês. ${ }^{6}$ It involves a complex system of relations and experiences that condition the objective opportunities and the subjective expectations of social recognition (Peres 2008). Despite the limitations of Galvão's model of acculturation, he perceived the importance of aviamento for understanding the social dynamics and processes in an Amazon border situation; ${ }^{7}$ such as the "extractive industries" in contrast to the formation of a "system of Indian reservations". On the Upper Rio Negro the mosaic of indigenous lands that were demarcated and sanctioned in the 199os buried this social configuration, directly confronting large extractive projects (mining) that operated according to a mercantile logic different from aviamento and that obfuscated the power of the patrões as the main antagonists of indigenous territorial rights. Meanwhile, on the Middle Rio Negro are found patrões who present themselves as the principal interests affected by the official regularization of the indigenous lands.

Observing the map on the following page, we see that the area currently in a conclusive phase of identification and demarcation studies is a zone that is free for the social reproduction of the aviamento regime. Mainly the left bank of the Rio Negro is a region rich in piaçabais. ${ }^{8}$

\footnotetext{
4 The aviamento regime is a mode of recruitment and exploitation of forced labor based on debt, in which the patrão (boss) lends goods at exorbitant prices (compared to the prices of the small shops in Barcelos and Santa Isabel do Rio Negro) in exchange for forest products (seringa $a^{\star}$, balata $a^{\star \star}$, sorva ${ }^{\star \star \star}$, piaçava $a^{\star \star \star \star}$, Brazil nuts, ornamental fish, etc.). The extractive workers (fregueses) become beholden to the patrão because of the debt contracted in the purchase of goods, and were required to deliver their production only to the patrão with whom they had a personal tie and an informal agreement based on moral commitments that supported a cycle of mutual favors and commitments (kinship, compaternity and neighborliness). There were no formal labor contracts or legally affirmed rights or payments in money for the extracted products. Under these conditions it was difficult for the extractive workers to reach a saldo or surplus (that is to exceed in the value recognized for the products the price of the goods advanced by the patrão). The patrão monopolized access and control to the respective commercial chain and held ownership of the boats needed for carrying large volumes of forest products.

*. Elastic gum extracted from hevea brasiliensis, an Amazon tree species, for the manufacture of rubber.

** Elastic gum extracted from Minilkara bidentata, a type of tree found in the Amazon, for the manufacture of balls, shoes, etc.

*** Elastic gum extracted from Couma Macrocarpa, a species of tree found in the Amazon, for the manufacture of bubble gum.

**** The fiber of a palm tree, Leopoldinia Piassaba, found in the Upper and Middle Rio Negro, used to manufacture brooms.

5 Patrão is the local designation for someone who controls the conditions of commercialization and financing of extractive production.

6 Freguês is the local designation for an extractive worker subordinated by commitments based on debt relationships with those who provide goods needed for support during the productive activity.

7 For the definition and use of the category of border that is relevant to this study: cf. Pacheco de Oliveira 2016a. See also Pacheco de Oliveira 2015 and 1988.

8 Piaçaba is a type of palm cut for the fiber in its leaves, which is used for brooms and other items. Piaçabais are the groves of these palms and piaçabeiros are the people who cut the leaves to extract the fiber.
} 
Map of Indigenous Lands and Conservation Units on the Rio Negro.

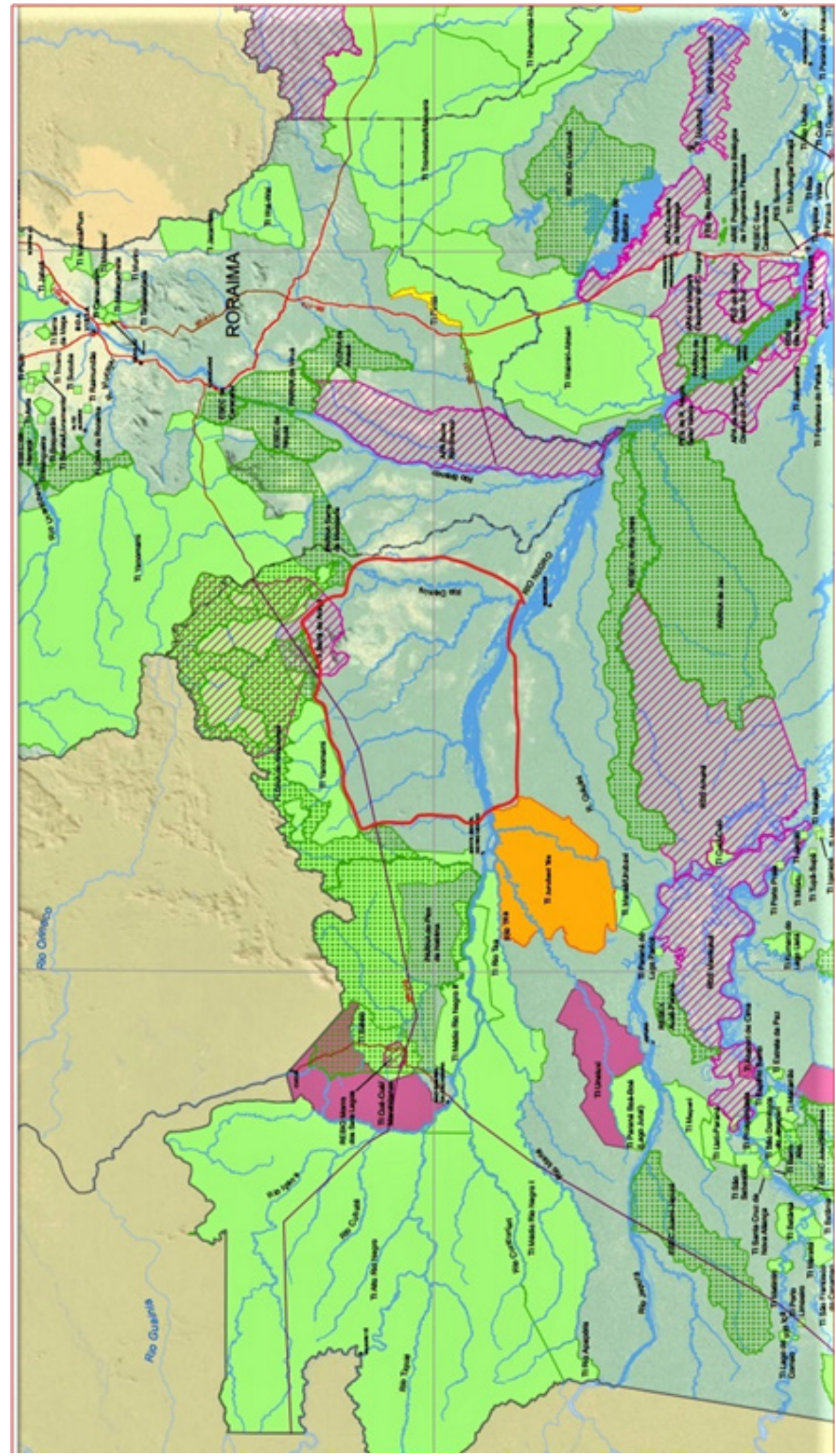

Map adapted from: Mapa Terras Indígenas e Unidades de Conservação na Amazônia Legal Brasileira [Map of Indigenous Lands and Conservation Districts in the Brazilian Amazon] (www.socioambiental.org), accessed on 12/10/2017. Observation: The indigenous lands in orange are identified; in violet they are declared; and in green are sanctioned. The polygon in red is the area that is in a phase of identification and delimitation. 
Since 2001, political pressure mounted from the indigenous associations of the Middle Rio Negro and in 2007 the Fundação Nacional do Índio [National Indian Foundation] (FUNAI) established two technical groups for identification and delimitation: one in the Jurubaxi and Téa river basins (both on the right bank of the Rio Negro); and the other for the right bank of the Rio Negro including the Caurés, Quiunini and Aracá, Demeni, Preto and Padauiri river basins (these four are on the left bank), encompassing the municipalities of Barcelos and Santa Isabel do Rio Negro. The anthropological reports of both working groups were considered unsatisfactory by the National Indian Foundation and for this reason two other teams were created to redo the respective studies. The Jurubaxi-Téa Indian Land was declared in 2017. In this article I will concentrate on the processes of indigenous territorialization, ethnicity and activism in the field of scope of the Aracá / Demeni and Preto / Padauiri river basins, where I coordinated the identification studies, ${ }^{9}$ since late 2009 . Sixteen communities were involved, embracing a majority Baré $(72 \%)$ population, totaling 781 people.

\section{Communities of the Padauiri-Preto and Aracá Demeni River basins: Population and Ethnic Identification.}

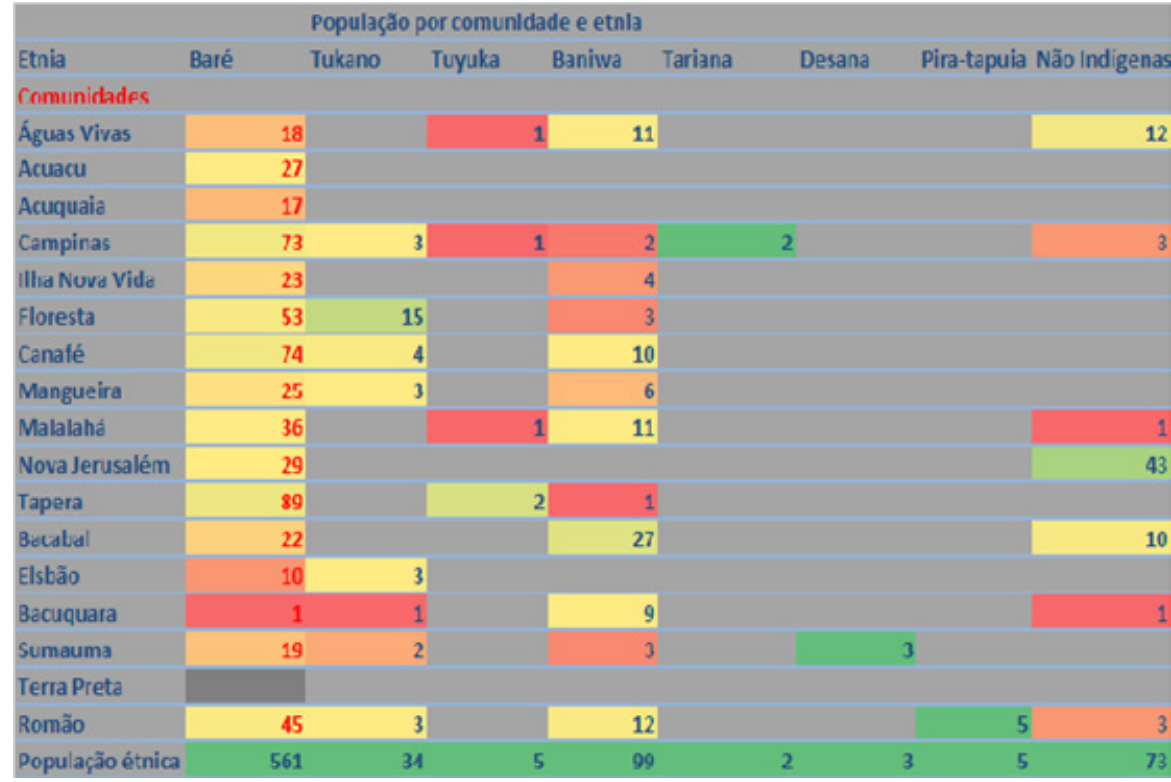

Source: Peres \& Nascimento 2016. (Population by community and ethnicity) 
Communities / Padauiri-Preto and Aracá-Demeni river basins.

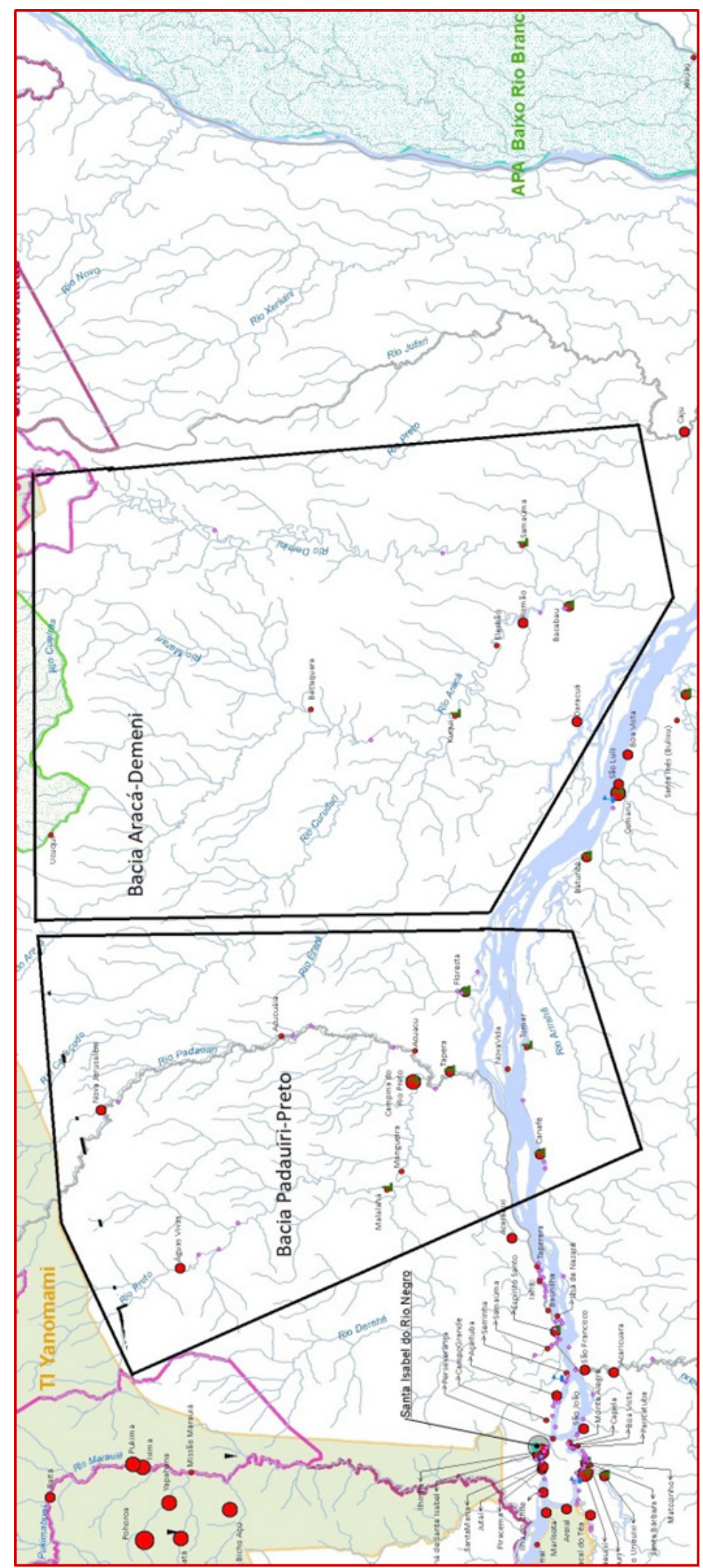

Adapted from the Mapa da Área de Abrangência da FOIRN [Map of the Area of Scope of Federation of Indigenous Organizations of the Rio Negro (FOIRN)] (www.foirn.org.br), accessed 14/10/17. 


\section{Tapuia, caboclo amazônico and immigrant nordestino: ${ }^{10}$ processes of territorialization, ${ }^{11}$ historic positionings and sociogenesis of the caboclo on the Middle Rio Negro.}

The main modalities for the imposition of Portuguese sovereignty on the Rio Negro were: the rescue troops, forts and religious missions that gave origin to various cities along the large river and its tributaries. Expeditions were organized that went up the Amazon River in search of "articles from the sertão [forest products]" (cacao, vanilla, cinnamon, cloves, sarsaparrilla, roots, "bitter barks", etc.), lumber and indigenous slaves. Their contingent was composed of some soldiers, a few clergy and a large number of Indian "archers", guides, "linguas" (translators), and rowers. In the mid seventeenth century the first rescue troops were formed that traveled up the Rio Negro (Monteiro 2000: 38-39).

In the seventeenth and eighteenth centuries the Portuguese crown disseminated forts throughout the Amazon basin, alongside which were founded settlements and missions, demonstrating a clear objective to populate the colony until its most distant limits. During the eighteenth century various forts were built along the Rio Negro. Merchants and Carmelite missionaries were active along the river and founded various villages such as: Santo Elias do Jaú, Aracari, Cumaru, Mariuá, São Caetano, Cabuquena, Bararuá and Dari (Monteiro 2000: 95). But the eighteenth century also saw prolonged wars against some insubmissive indigenous peoples; including the Manao, who together with the Tarumã and the Baré, constituted part of the indigenous population in the lower Rio Negro (Leonardi 1999: 31).

In 1728 , the village of Nossa Senhora da Conceição do Mariuá was founded by the Carmelite monk Matias São Boa Ventura. It reached an estimated population of 2,00o people, from various ethnic origins, such as: Werekena, Baniwa, Baré and Passé. On May 6, 1758, it attained status of a Vila and was given the name Barcelos (see the map on page 4), becoming the center of the captaincy of São José do Rio Negro (Monteiro 2000: 123-137). ${ }^{12}$ Barcelos gained urban improvements and economic incentives, because it was also chosen as the location for the meeting of Portuguese and Spanish commissions for the demarcation of borders, and for two years was home to the governor of the captaincy of Grão Pará and Maranhão, Francisco Xavier de Mendonça Furtado - brother of the Marquês de Pombal — who led the Portuguese delegation. Other settlements that gained village status - such as Carvoeiro, Moura, Moreira, Tomar and Airão served as strategic points in the conquest and occupation of the Amazon by the Portuguese colonizers.

The excursions to descend the rivers continued during the turn from the eighteenth to the nineteenth century. The settlements on the Lower Rio Negro included indigenous contingents of various ethnicities, including those from other river basins. Nevertheless, the forced recruiting of Indians to fight in the Paraguay War led to the decline of various settlements, whether because the youth did not return or because

\footnotetext{
10 Tapuia refers to the descendants of Indians who had lived in the missionary settlements in the 17th and 18th centuries; caboclo amazônico [Indian considered acculturated] and imigrante nordestino [immigrant from Brazil's Northeast] (or arigós) until the period of rubber tapping, diversification of the extractive economy and consolidation of the aviamento regime in the late nineteenth and twentieth century.

11 I use here João Pacheco de Oliveira's concept of territorialization: "In this sense, the notion of territorialization is defined as a process of social reorganization that implies: 1) the creation of a new sociocultural unit through the establishment of a distinct ethnic identity; 2) the constitution of specialized political mechanisms; 3 ) the redefinition of social control over the environmental resources; and 4) the re-elaboration of the culture and of the relation with the past" (Pacheco de Oliveira 2016b: 203).

12 The Amazonian northeast was a colonial frontier of concern to the Portuguese Crown due to the missionary activities linked to the Spanish king and the negotiations over the territorial limits between the two colonies. On the other hand, since the early eighteenth century, the commercial circuits in which the Dutch and Indigenous groups were engaged in the Upper Rio Branco extended to the Lower Rio Negro through merchandise brought by those indigenous people to the settlements of this region. For this reason, a solid governmental structure was implanted, that is, the greater presence of the colonial Portuguese state, through the creation of the captaincy of São José do Rio Negro, in 1757.
} 
of a climate of terror that drove many residents to flee. They were also fleeing the heavy burden of the exploitation of indigenous labor by the colonists, imposed more brutally with the end of the missionary settlements and the creation of the Diretorio. ${ }^{13}$

At the end of the eighteenth century, the end of the Diretório did not lead to a better situation for the indigenous population that was forcefully recruited in the most distant settlements on the smaller rivers and igarapés (very small rivers) to work in services and public construction projects, in the extraction companies of the traders or on the farms of the colonos (colonists). This coercive type of mobilization of the labor force, which at the core involved corporal punishment of indigenous workers, remained known locally as agarrações and had the complicity of the directors (Leonardi 1999: 107-108). ${ }^{14}$ The prohibition of the colonial authorities did nothing to impede the compulsory removal of indigenous men and women from caring for their own roças (small plantings) and families. The conditions were established for the engagement of many indigenous residents from the colonial nuclei of the Middle Rio Negro in the revolt of the cabanos. ${ }^{15}$

The decline of the main villages (Airão, Moura, Carvoeiro, Barcelos, Moreira and Tomar), which had become reduced to a few houses of taipa (mud) and churches in ruins, was also due to the Cabanagem, because this political movement interrupted trade, navigation, extractive activities, food production and supply. The implacable repression of the Cabanos after the defeat of the movement afflicted many tapuias who were involved in the conflict, provoking the abandonment of many settlements and villages. One traveler found only two villages on the Rio Negro, Barra do Rio Negro ${ }^{16}$ and Barcelos, and both presented extremely precarious conditions by the standards of urban life of the time. In 52 years (1790-1842) the number of residences (identified as fogos (fireplaces) in Barcelos fell from 640 to 74 (Leonardi 1999: 118). The agarrações, as well as the repression of the Cabanos movement, were important factors in the population movements on the Rio Negro.

In the second half of the nineteenth century, however, a new possibility appeared for the precarious urban areas of the Middle and Upper Rio Negro, due to the introduction of steam navigation in the Amazon in 1854 (Leonardi 1999: 122-123). The implantation of a regular transportation line for goods and people from Manaus to Santa Isabel do Rio Negro drove the extraction of piaçava, breu (vegetal resin), estopa (coconut fiber), dried fish and salsa (plant used in cooking). With the increased extraction and sale of rubber, the number of steamboats increased even more. However, it was in the late nineteenth century, with the rubber cycle, that the social and political elite of the Lower Rio Negro sought a possible economic and demographic recovery in the region. The composition of the population changed drastically with the intense immigration of people from Brazil's Northeast (Cearenses, Paraibanos etc.) who provided needed labor - as well as small merchants - to provide raw materials to the exporting companies and to English financial capital, both located in Manaus. It was at this time that the network of aviamento was implanted and linked to large commercial stores in Manaus, the merchants of small urban centers on the Rio Negro, the smaller merchants located at the mouths of the tributaries and igarapés and the workers in extraction (Pacheco de Oliveira 2016a: 134-137). Many commercial houses were installed in the main urban

\footnotetext{
13 The Diretório was a legal-political order (1757-1798) that redefined relations between colonizers and indigenous groups, transforming indigenous settlements into villages, imposing use of the Portuguese language, regulating the use of indigenous labor and granting lands to colonists in villages where they lived, stimulating miscegenation and commerce with non-Indians and instituting the figure of the director as a tutor directly in charge of the civilization of the Indians.

14 The agarrações were activities for capturing indigenous people who lived in the settlements and villages of the Middle and Lower Rio Negro, which began soon after the end of the Diretório in the late eighteenth century and early nineteenth century.

15 The Cabanagem was a popular revolt that began in Belém and spread through a vast region of the Amazon basin, also reaching some parts of the Northeastern coast. This political movement lasted five years (1835-1840) and was harshly repressed by the regent government, resulting in more than thirty thousand deaths. About the revolt of the Cabanos see Harris 2010.

16 In 1850, Amazonas became a province, separated from Pará. In 1856 the former village of Barra do Rio Negro received the definitive name of Manaus.
} 
centers on the Rio Negro, introducing new members of the local elite as well as a new lifestyle in which the consumption of conspicuous goods (lipsticks, wines, porcelain cups, ivory combs, fabrics, musical instruments, fireworks, shotguns and munitions, etc.), coming from the capital (Manaus) gave a tone of refinement and superiority that marked the social distinction among patrões and fregueses, between civilization and backwardness. Meanwhile, the owners of the commercial houses of Airão, Carvoeiro, Moura, Barcelos, Tomar, Moreira, Santa Isabel and Cucuí sought to imitate the ostentatious life of the Manaus oligarchy (Leonardi 1999: 91-128).

The local intermediaries spread along the various rivers were integrated in a web of personalist relations, through which circulated mutual obligations and favors, whose center was the firm of the Portuguese immigrant, J. G. Araújo. With the progressive drop in rubber prices in the international market after 1914, and the competition with the production of rubber in Southeast Asia, the river navigation dropped considerably and economic alternatives, previously abandoned or relegated to a secondary plane, were reconsidered - such as the extraction of Brazil nuts and piaçava. In the 1940s, during World War II, the extraction of rubber gained new strength with the arrival of the "rubber soldiers" ${ }^{{ }_{17}}$ from Rio de Janeiro and Brazil's Northest (IBGE 1957: 114). According to the demographic census of 1950, Barcelos was one of the least populated municipalities of Amazonas state $(4,911)$, but the largest in territory in the state and perhaps in Brazil. Only 970 people lived in the center of the municipality. Piaçava became the main product of extraction, stimulating the recruitment of labor in the indigenous communities of the Upper Rio Negro, para as colocações ${ }^{18}$ of the Aracá, Padauiri and Preto Rivers, due to the scarcity of workers caused by the decline of rubber extraction. The mechanism of debt formation was the pillar of all the other extractive activities, including the capturing of ornamental fish. ${ }^{19}$

In the twentieth century, the urban centers, settlements and farms appeared and disappeared according to the dynamics of the productive and commercial chain of extraction (of seringa (rubber), balata, Brazil nuts, piaçava, piaba, etc.); as well as the flow of indigenous families who moved from the Upper Rio Negro, recruited as a labor force and inserted in the networks of personal dependence and subordination that constituted the ties between patrão and freguês, as well as the positions and identities of caboclos in contrast to the arigós (Northeasterns who also assumed coercive control of the indigenous who worked in extraction).

The tapuias and Amazon caboclos were joined by the nordestinos (natives of Brazil's northeast),,$^{\circ 0}$ (or arigós, the regional designation by which the caboclos distinguished themselves) to certify the highly boasted disappearance of the indigenous people from the Middle Rio Negro. ${ }^{21}$ This long historic process of social construction of the caboclo, constituted by a series of material and symbolic violence against the indigenous peoples, resulted in the dilution of the tapuias (generic indigenous descendants of indigenous residents of villages at the missions before the creation of the Diretório) at the heart of the miscegenated Amazon population with migrants from Brazil's Northeast. The tense and combative encounter of the tapuia and the immigrants from the Northeast (as socially constructed historic positions) resulted in a new category,

\footnotetext{
17 About the exploitation of rubber in the Brazilian Amazon during the Estado Novo [New State] period, cf. Garfield 2014. For an approach to the rubber cycle at the heart of a social history of the Amazon, cf. Weinstein 1993.

18 Colocações are a system in which extractive workers process the piaçava and deliver it to the patrão.

19 The piabeiros (fishermen) are highly exploited by the bosses who demand enormous production of piabas (small fish) in exchange for goods (whose prices are much lower than at the shops in Barcelos or Santa Isabel do Rio Negro) supplied in advance. If they reach a surplus, the fishermen can receive it in money and look for another boss who pays better, or purchase more manufactured goods, once again loaned against their next job. In the 1980's and 9o's, the extractive economy of ornamental fish grew gradually with the falling prices of other forest products such as balata, sorva and rubber, even exceeding the cutting of piaçava, coming to be responsible for 60\% of municipal income (Prang 2001: 47).

20 These categories should not be considered in an exclusive and reified manner, but should be seen as relational categories that are socially constructed in historic processes, as positions that refer to social spaces of identity construction and or asymmetrical relations of reciprocal recognition.

21 Victor Leonardi inserted his approach to the decadence of the old village of Airão in this perspective of decimation or expulsion of the autochthone peoples, contributing to the academic consecration of the indigenous invisibility, based on their supposed extinction, in the Middle Rio Negro (Leonardi 1999: 197).
} 
the caboclo Amazônico, which removes any tangible expression of cultural differentiation. There was a process of ethnogenesis in the Middle Rio Negro in which the memories and identities are reformulated at the heart of a movement of social construction of demands for citizenship supported by identity politics, contrary to the supposed inexorable route that leads to tribal societies, passing through generic Indians (whether in settlements, detribalized or tapuias), to the caboclos who were completely integrated into the marginalized and "backwards" sectors of national society as peasants excluded from the main political and economic flows of the country. Nevertheless, this ethnogenesis in the Middle Rio Negro is inserted to new processes of territorialization in the twentieth century, related to the Salesian missionary activity and the formation of a network of indigenous associations on a regional scale.

\section{Missionaries, the Military, Non-Governmental Organizations (NGOs) and the Federation of Indigenous Organizations of the Rio Negro (FOIRN): developmentalism, environmentalism and the formation of associations in the Rio Negro basin.}

The Salesian missionary policy of the 1970 and 1980 os revealed a modification in the principle programs to emphasize "community development", through courses for training teachers, local leaders (known as captains, administrators or presidents, according to the region of the Rio Negro) and pastoral agents. ${ }^{22}$ The reformulation of the missionary practice conceded a relevant role to the training of lay and catechist agents; to activities located in the indigenous settlements (known as itinerâncias); ${ }^{23}$ and to the participation of lay people in the planning and evaluation of the parochial work (on parochial councils); with decreased emphasis on boarding schools and a limitation of the range of action of the central offices. The formation of associations was encouraged, mainly among young people, whether for strictly religious purposes (through the organization and participation in events of the parochial agenda) or to promote public benefits (health, education, economic support, politics, leisure, etc.) (Peres 2013: 57-97).

The inculturation proposed that the missionaries learn the indigenous language, and the introduction of elements of indigenous traditions (objects, musical instruments, dances, songs, etc.) into the Catholic liturgy. The indigenous were called on by the Salesians to participate in the preparation of these signs of ethnic authenticity in Catholic spaces of interlocution (parochial assemblies, encounters and courses for Pastoral and lay leaders etc.). From this perspective, the pastoral action must understand the reality in which it is inserted and position itself in relation to it. The social struggles were framed within a religious language, while the religious demands were framed in the code of activism in defense of the universal rights of man.

The direct action of the state with the indigenous peoples in the Rio Negro region was considerably limited in relation to the powerful competition of the Salesian missionary structure implanted with government support. In the 1920s, the Indian Protection Service (SPI) ${ }^{24}$ was established based on

\footnotetext{
22 The Salesians settled in the Rio Negro in 1914-1915, with the creation of the Apostolic Prefect (later transformed into a Prelacy) in São Gabriel da Cachoeira (Jackson 1984). Their domain then broadened with the foundation of various pastoral units: Manaus (1922), Barcelos (1925), Taracuá (1929), Iauareté (1929) and Pari-Cachoeira (1940), Tapuruquara (1942), Içana (1950), Cauburis (1958), Cucuí (1967) and Maturacá. In 1925 the Apostolic Prefect of Rio Negro was raised to a Prelacy, subordinated to the Missionary Inspector's office in Manaus, and in 1981 became a diocese. The Salesians attacked some social institutions, insisted in imposing the use of the Portuguese language and invested in the education of children in boarding schools.

23 The itinerâncias were periodic visits of Salesian missionaries to the indigenous settlements to administer the sacraments (marriage, baptism, confirmation, extreme unction, requiem mass and Sunday mass) and corresponded to a regular monitoring in the process of (trans)formation of ecclesiastic base communities. The pastoral reports statistically registered the results of the itinerâncias as missionary productivity, rituals of institution of the ecclesiastic community through meetings, religious festivals, celebrations and sacraments (Peres 2013: 80-82).

24 State indigenous agency created in 1910 and extinguished in 1967, when it was substituted by the current Fundação Nacional do Índio [National Indian Foundation] (FUNAI).
} 
geopolitical objectives of national integration of this border region. ${ }^{25}$ Its tasks were to control trafficking of indigenous labor, conflicts involving activities of Colombian traders in Brazil and to monitor the catechizing activities. For this reason, the focus of action chosen was the Vaupés River and its tributary the Papuri.

In the 1960 s, more specifically after the military coup of 1964, the Brazilian state enacted another strategy of affirmation of national sovereignty in the Rio Negro: creating the Rio Negro Forest Reserve, which covered the entire territory of the municipality of São Gabriel da Cachoeira and established an enormous reserve of natural resources for future economic exploitation. The construction of the highway Perimetral Norte (BR-307), which crossed the forest reserve, intensified the presence of state agencies and the military contingent on the Upper Rio Negro. The official indigenous network received a new impulse with the reactivation of the indigenous posts of the ancient Indian Protection Service by the National Indian Foundation (FUNAI). The opportunity to work on construction of the highway and receive a plot distributed by the National Institute for Colonization and Agrarian Reform (INCRA) along highway BR-307 triggered an enormous flow of migrants from Brazil's Northeast (particularly from Ceará and Maranhão states). The population shifts on the Rio Negro also included the Indians, who went mainly to São Gabriel da Cachoeira, which became a regional point of convergence of economic activities and opportunities to access public services (Peres 2013: 117-140). ${ }^{26}$

Since the 1970's, the indigenous peoples in Pari-Cachoeira demanded a single area and not a fragmentation of their traditional lands. Indigenous militancy was institutionally materialized through the entity Christian Encouraged Family Union (UFAC). ${ }^{27}$ There were also institutional responses from FUNAI to that context. ${ }^{28}$ In 1986 , leaders of the Union of the Indigenous Communities of the Tiquie River (UCIRT) traveled to Manaus to obtain information from the regional administrator of the National Indian Foundation about the Projeto Calha Norte. ${ }^{29}$ The assembly for the creation of Federation of Indigenous Organizations of the Rio Negro (FOIRN) ${ }^{30}$ resulted from a complex process of political articulation among indigenous leaders and government authorities..$^{31}$ The focus was a strongly politicized ethnic identity movement, which formulated demands for participation in decisions about the fate of the Upper Rio Negro, bringing to the region the debate about a geopolitical and developmentalist plan of the Brazilian state that had been secretly drafted in the backrooms of government leadership. If on one hand the goal

\footnotetext{
25 It should be highlighted that nearly a decade earlier (in 1912), an Indian Protection Service post for attraction and pacification was established, led by indigenous agent Alípio Bandeira, on the Jauaperi River (Lower Rio Negro), to engage the Waimiri-Atroari. A year earlier, he had commanded an expedition up the Jauaperi River, leaving from Moura (Carvalho 1982).

26 The migration of indigenous families from the communities and sitios (small plots of land) to the municipal center also took place because of the closing of the Salesian boarding homes in the late 1970s.

27 When it was created, the Union of the Indigenous Communities of the Tiquié River (UCIRT) was opposed by the Salesians who supported the Christian Encouraged Family Union (UFAC), which was founded in the early 1970s, and terminated in 1984, after differences among the indigenous leaders of the Pari-Cachoeira district because of the denunciations of Álvaro Tukano at the Russell Tribunal in 1980 against the action of Catholic missionaries on the Rio Negro.

28 In 1976, a working group was established to identify the land, which formulated a first proposed area. It followed the territorial model of Salesian power, proposing the demarcation of three distinct and contiguous units: Pari-Cachoeira (1.020.00o ha), Iauareté (990.00o ha) and Içana-Aiari (896.00o ha). In 1985, another working group proposed the inclusion of the mining areas of the Serra do Traíra in the Pari-Cachoeira Indian Land (which was increased to $1,418,000$ ha). The following year, a new proposal from FUNAI expanded even more the limits of this indigenous land (to 2,069,00o ha). It continued to encompass the Serra do Traíra, recognized as traditional territory of the Maku people.

29 This was a government project for integration of the region north of the courses of the Amazon and Solimoes rivers, which included development policies and plans for military occupation, mainly of the international border regions that was proposed and executed during the government of Brazilian President José Sarney.

30 Federação das Organizações Indígenas do Rio Negro.

31 The II Assembly of the Indigenous Peoples of the Rio Negro was held from April 28-30, 1987, in the sports gymnasium of the Salesian school in São Gabriel da Cachoeira, Amazonas. The importance of the Upper Rio Negro for achieving the government objectives for the region is indicated by the presence of the Secretary General of the National Security Council, General Bayma Denis, at the event. Also present were representatives of various government agencies, indigenous organizations and support entities (União das Nações Indígenas/[The Union of Indigenous Nations]UNI, Conselho Indigenista Missionário[The Indigenous Missionary Council]/CIMI and the Centro Ecumênico de Documentação e Informação/[The Ecumenical Center for Documentation and Information] CEDI), mining companies (Paranapanema and Gold Amazon) as well as local merchants and politicians.
} 
was to negotiate resources and legal recognition of the indigenous lands, that is the very conditions for implantation of the Calha Norte Project; on the other it was to change the direction of a state structure that was being implanted to achieve objectives not foreseen by the project: the organization of the indigenous movement according to a federative, vertical and centralized model. The Federation would be the link between government, communities and the indigenous movement.

The creation of the Federation of the Indigenous Organizations of the Rio Negro, the new and conflicting processes of occupation and use of natural resources in the Upper and Middle Rio Negro ${ }^{32}$ and the recognition by the Federal Constitution of 1988 of the right of indigenous peoples and their organizations to represent themselves directly in the courts and before the Brazilian state, stimulated the increased formation of associations as a privileged from of political mobilization and organization of ethnicity There was a culmination of a phenomenon of transformation of the stigma of native ancestry into ethnic pride, of the moral recuperation of indigenous ethnicity as a positive element of social recognition. The deliberate and reflective efforts to redefine ethnic borders have been generated in an emerging and relatively autonomous discursive space, which was no longer exclusively linked to the semantic field of Salesian missionary action and its new strategies for ecclesiastic control.

The movement to form associations, after the Federal Constitution of 1988 , whose focus is the concept of universal recognition of a diversified citizenship, substituted Christianity after the Second Vatican Council of 1962, whose central principle is the preferential option for the poor. New allies arose: non-governmental organizations, in the place of the Missions; and a new non-indigenous mediator: the anthropologist-advisor (as well as other professionals who would occupy this role), instead of the itinerant priest. And a new type of action developed: scientific and technical collaboration instead of religious proselytizing, while both were politically engaged. A public sphere emerged around "Indianness", an incipient local and indigenous civil society pressured government agents to dialog. ${ }^{33}$

From 1987 to 1992 twelve new associations appeared (ISA 2000: 267-268) in a climate of sharp conflict among the indigenous population around the various proposals for demarcation in indigenous colonies or on continuous territory. The agglutinating criteria was geographic (a set of communities located in a stretch of the river, on one or more rivers, or in a district), and its composition was ethnically diversified. This demonstrated that the current distribution of the ethnic groups along the rivers, their social organization in communities, and the common problems of a group of communities established in a given location shaped the organizational model of political mobilization of ethnicity on the Rio Negro. Some more immediate motivations can be identified: dissidence towards an already existing association, a demand for political representation and mobilization of a group of communities still not integrated to the emerging organizational structure or inserted in an association where it does not have its own visibility and expression of sectorial interests (gender, occupational etc.) (Peres 2013: 140-193).

In the early 199os, the physical and logistical conditions (offices, administrative equipment, communication, transportation etc.) of the Federation of the Indigenous Organizations of the Rio Negro were extremely precarious: a small house, a table and a borrowed typewriter. The only local support for the organization came from the Catholic Church of São Gabriel da Cachoeira. The Federation began to establish itself through international cooperation when it obtained financial support from a Belgium finance agency, the BroederlijkDelen. This was the first step in the expansion of a range of connections and the search for more durable partnerships with indigenous organizations and support entities on multiple scales.

\footnotetext{
32 Triggered by a strong presence of the mining companies and gold diggers.

33 These in turn, considering this demand for participation, strategically recruited leaders to their ranks of employees and sought to steer the emerging indigenous movement to its geopolitical objectives. They manipulated categories of the regional interethnic imaginary, interpreting them according to the then dominant official concepts of "isolated Indian or arredio" and "integrated or cultured Indian". In this context, development and complete guarantee of territorial rights were presented to many as incompatible; tradition and modernity could not be conciliated.
} 
With the expansion of the networks of indigenous associations, the demands for access to public benefits were closely linked to reflexive acts of preservation of the "natural and cultural patrimony" of the Rio Negro peoples. The connection of the local problems of the indigenous peoples of the Rio Negro with the interests of citizens of the first world in the preservation of tropical forests provided the Federation of Indigenous Organizations of the Rio Negro with symbolic capital that was converted into institutional partnerships with foreign environmentalist organizations. This process substantially expanded the agenda of indigenous struggles, embracing the themes of transportation and communication, education and healthcare, cultural valorization and economic alternatives.

The signing of a cooperation agreement between the Federation of the Indigenous Organizations of the Rio Negro, the Ecumenical Center for Information and Documentation (CEDI) ${ }^{34}$ and the Austrian Institute for International Cooperation (IIZ) ${ }^{35}$ in 1993 sacramented the insertion of the indigenous movement of the Rio Negro in the European campaign in defense of the planet's ecological equilibrium, the "Climate Alliance". The Ecumenical Center and the Institute for International Cooperation assumed a more regular and permanent role in providing assistance and financing to a broad range of activities of the indigenous movement in the Rio Negro. Expanding and consolidating the framework of financial support for the Federation, its core actions and conditions for the institutional strengthening were redefined, and other fronts of actions were undertaken that had previously been considered specific projects.

The administrative structure of the Federation of Indigenous Organizations of the Rio Negro grew along with the increasing financial and material resources and the need to register, file and process information about the planning, execution, evaluation and promotion of a growing and complex set of tasks and demands. It also invested in transportation and communication logistics (boats and motors, radio systems), needed to overcome the geographic obstacles that impeded the approximation and consonance of the policies of the Federation with the affiliated associations and indigenous communities. Other support agencies helped to provide local organizations with means of transportation to conduct both their political activities in the communities and sitios and to improve the conditions for sale of local products (manioc flour, piaçava, crafts, etc.). The radio communication systems were also expanded with support of other partners.

With a more positive perspective, supported by an official guarantee of indigenous lands in the Upper and Middle Rio Negro, ${ }^{36}$ territorial management and the creation of economic alternatives received greater attention through the preparation of pilot projects. The strategy for the sustainability of the communities was clearly defined by selecting some of them to conduct experimental pilot projects in the fields of aquiculture, agriculture, aviculture, mining, crafts and ecotourism, which would be diffused if successful. The initiatives that were considered as laboratories for future proposals of a macro-program of regional sustainable development were that of aquiculture on the Upper Tiquié, crafts on the Upper Tiquié and education on the Upper Içana and Upper Tiquié. Other initiatives continued to receive financing, and a permanent technical, logistic and financial support structure was mounted, which concentrated the most intensive and systematic investments of the partnership between the Federation, the Brazilian entity Instituto Socioambiental (ISA) ${ }^{37}$ and the Austrian Institute for International Cooperation in a few selected areas. New opportunities arose for articulation between the market, state, civil support entities and indigenous society organized in associations.

\footnotetext{
34 Centro Ecumênico de Informação e Documentação.

35 Instituto de Cooperação Internacional da Áustria [Austrian Institute for International Cooperation].

36 Delimitation (through the issue of a ministerial edict) of the Indigenous Land Alto Rio Negro, Middle Rio Negro I, Middle Rio Negro II, Apapóris and

Téa. In 1998, theses five indigenous lands were approved.

37 Instituto Socioambiental, [Socioenvironmental Institute] created in 1994.
} 
The frontier of formation of associations on the Rio Negro shifted to the Papuri, Upper Içana/Aiari and Upper Tiquié Rivers and to the most distant areas of the Middle Rio Negro (closest to the city of Santa Isabel do Rio Negro) where some associations were being created. The invasion of enormous contingents of gold diggers on the Upper Içana and Cauaburis rivers increased concern for demarking the indigenous lands of the Upper and Middle Rio Negro and triggered the creation of indigenous associations. In the first half of the 1990s, the associations of the Middle Rio Negro were able to suggest and implement activities in their respective communities due to the entrance of resources (financing for assemblies, boats, aluminum skiffs, outboard and inboard motors, radio equipment, office suppliers, agricultural implements etc.) motivated by the need to increase political mobilization due to the invasion of gold diggers and miners. The Autonomous Indigenous Census conducted in 1992 should also be mentioned as an important factor in the mobilization of the communities and rise of associations on the Middle Rio Negro. The physical demarcation of the Indigenous Lands of the Middle Rio Negro I and II - due to its participatory character - in 1997, maintained the dynamism of these local organizations. With the guarantee of indigenous land conquered and the decision taken in the decision making bodies of the Federation to concentrate efforts of implementation of sustainable development and cultural valorization through demonstration projects ${ }^{38}$ on the Upper Tiquie and the Upper Içana, these associations still did not have the conditions (such as permanent assistance, continuous and localized training, a constant flow of resources) to remain active and dynamic.

\section{"Making community" and "closing the river": Family trajectories, reproduction strategies and compulsory forms of mobilization of the labor force.}

In the municipality of Barcelos, unlike Santa Isabel do Rio Negro and São Gabriel da Cachoeira, the indigenous population is numerically a minority. Considering only the Middle Rio Negro, according to the last demographic census (2010), Santa Isabel (formerly Tapuruquara) encompassed 62,846,382 Km and was among the five municipalities that had the largest indigenous population in Brazil in absolute terms and was sixth in terms of indigenous proportion of the total population..$^{39}$ More than half of the population of the municipality is indigenous $(59,24 \%)$, corresponding to 10,749 individuals. In twenty years the indigenous population grew in absolute and relative terms, increasing more than the non-indigenous population. From 1991 until 2000 the indigenous population decreased sharply, while the non-indigenous population grew a little. From 2000-2010, the demographic tendency changed radically: the indigenous population grew sharply, exceeding the non-indigenous population, which grew very little. The reasons for this considerable demographic fluctuation are complex and difficult to define, but may be the result of both the movements of migration (to other Amazon municipalities or even to other states), as well as movements of ethnic affirmation, or both factors combined.

It should be remembered that the 199os were especially difficult for the indigenous groups in the municipality because of the presence of gold diggers and miners who prohibited access to certain areas with resources essential to the indigenous communities and caused other problems such as criminality, violence, alcoholism, etc. (ISA 1996: 146-147). This situation was overcome with the demarcation and

\footnotetext{
38 The Demonstration Projects Subprogram (PDA) was "created in 1995 and began operating in 1996 when it initiated support to the first projects. [...] Implemented by the Ministry of the Environment in the realm of the Pilot Program for the Protection of Tropical Forests (PPG7), it mainly received support from German International Cooperation [...] In the first phase (1995 to 2003), the PDA supported 194 projects, with 147 in the Amazon and 47 in the Atlantic Forest" (http://www.mma.gov.br/apoio-a-projetos/sociobiodiversidade, accessed on 20/12/2017).

39 Considering only Northern Brazilian or Amazonas state, Santa Isabel is in fourth place in indigenous population, behind only São Gabriel da Cachoeira, São Paulo de Olivença and Tabatinga. (Total, Indigenous, Non-indigenous)
} 
ratification of indigenous lands in the municipality in the second half of the 199os; and later, after 1999, the implementation of the Special Indigenous Sanitary District, and the process of identification of Indigenous Lands after 2007 sparked the collective mobilization of ethnic identity.

\section{Population Indigenous | Non- Indigenous - Santa Isabel do Rio Negro (1991-2010)}

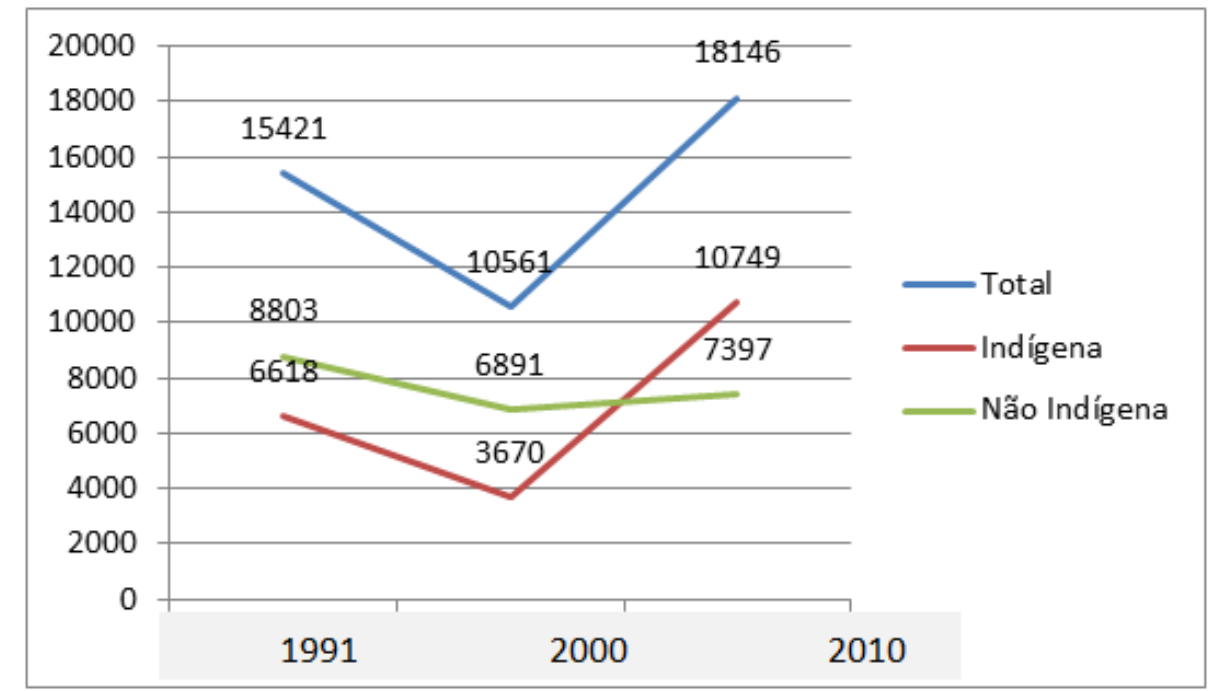

Map based on http:||indigenas.ibge.gov.br/graficos-e-tabelas-2

(Total, Indigenous, Non-indigenous)

Barcelos, which is older than Santa Isabel, and also known by its former name, Aldeia de Mariuá, was founded in 1728 and was the first center of the captaincy of São José do Rio Negro. This municipality encompassed 12,313,841.70 km and a population of 25,718. Barcelos is among the ten Brazilian municipalities with the highest indigenous populations, in ninth place..$^{40}$ Nearly one third $(32.53 \%)$ of the population is indigenous. The indigenous population grew more than the non-indigenous population, corresponding to greater portions of the total population over twenty years. While from 2000 to 2010 the non-indigenous population decreased, the indigenous population grew, although less sharply than in the previous period.

40 Considering only the Brazilian North and Amazonas state, Barcelos is the municipality with the seventh and sixth highest indigenous population respectively. 


\section{Indigenous Population/ Non-Indigenous Population - Barcelos (1991-2010)}

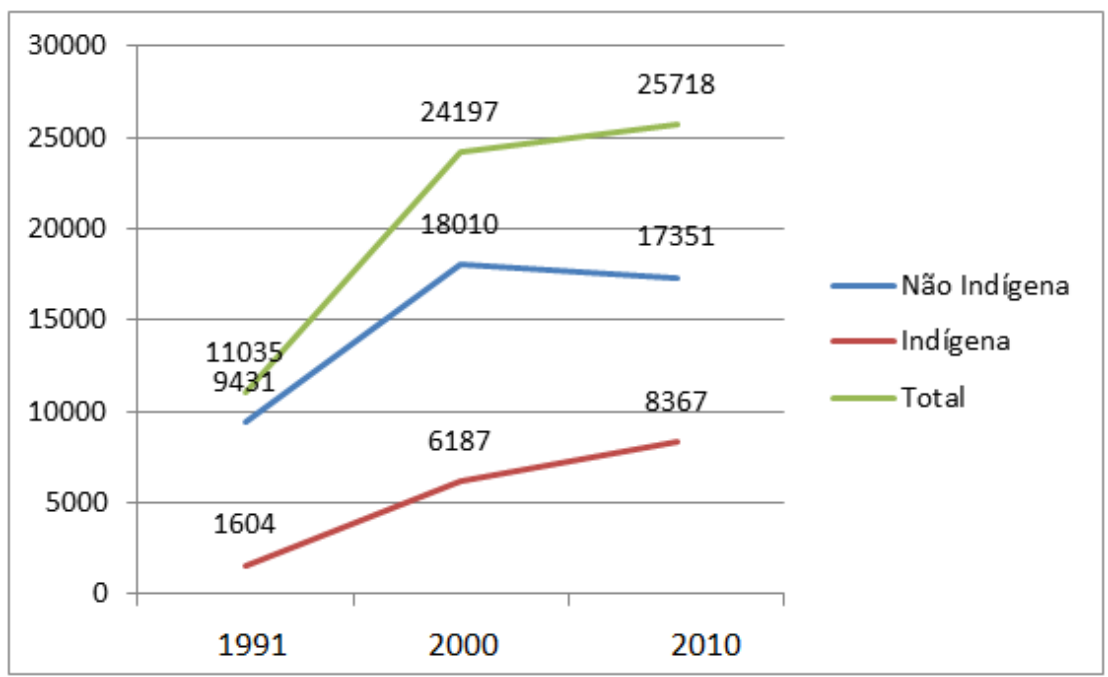

Map based on http:/|indigenas.ibge.gov.br/graficos-e-tabelas-2

(Total, Indigenous, Non-indigenous)

As can be seen, the population of the municipality of Santa Isabel do Rio Negro decreased considerably in the 1990s, probably because of both migration (due to the presence of mining that restricted access to areas of natural resources essential to the sustainability of the communities), while the indigenous and total population of Barcelos grew considerably. We can thus deduce that a part of the total and indigenous population of the neighboring municipality migrated to Barcelos. In the following decade, the indigenous population of Barcelos grew at a slower pace, concomitantly to a sharp increase in the indigenous population of Santa Isabel (and even exceeded the non-indigenous population), which may have received a return of some of the indigenous people who had emigrated in the previous decade. This is very probably due to the intense flow and mobility of the indigenous groups on the Rio Negro, but which simultaneously sustained the absolute and relative growth of the indigenous contingent in both municipalities. We must also consider that, as we have indicated, the social conditions of public affirmation of ethnic identity had changed, encouraging more individuals to declare themselves to be indigenous in the censuses conducted by the Brazilian Institute of Geography and Statistics (IBGE). This explains the register of such a small portion of self-declared indigenous in 1991, when prejudice and discrimination were still very strong in the municipality, the indigenous movement had not increased and there were no specific public policies for the indigenous (in education and healthcare for example).

Spatial mobility is fundamental to the reproduction of the domestic groups and the movement to urban centers is inserted in this complex web of relations (economic, political, religious, of kinship, etc.) and of flows (of people, objects and meanings) regularly maintained between "community" and "city". Many indigenous families who reside in the municipal centers have homes and roças (small farm plots) in communities or sítios/small rural plots, where they go during the school holidays of their children; since they have relatives in the communities and sitios, with whom they share norms of access and use of natural resources. The cities of Barcelos and Santa Isabel do Rio Negro grew in the last four decades from the migration of an important indigenous populational contingent that settled in the neighborhoods of the urban periphery. Many reached the city after having passed through and lived in the communities, sítios 
and other urban nuclei of the Rio Negro and many others are children or grandchildren of the "caboclos of the Upper Rio Negro" who were recruited by the patrões to work in extraction under the aviamento regime in seringais, piaçabais (rubber-tapping, palm-cutting) or gathering Brazil nuts, etc (Peres 2008: 156-162).

The processes of indigenous territorialization, affirmation of ethnicity and formation of associations can only be understood in the region under analysis by considering this interplay of tensions between two antagonistic and competing territorialities. This antagonism is synthesized in two expressions formulated by these subjects: "closing the river", as an action promoted by the bosses and the logic of the aviamento regime; and "making community", as an action promoted by the indigenous fregueses and the logic of social reproduction of domestic groups. That is, tension and antagonism between subordination and autonomy are subjacent to the relations between patrões and fregueses. The dynamics of "making community" that is at the base of the social reproduction strategies of the indigenous families (of the collective modalities of use of natural resources and territorial occupation) implies the mobility and multi-locality that are restricted by the dynamics of "closing the river" subjacent to the aviamento system. The "home" / "farm" versus the "colocação"41 / "merchandise".

The trajectory and the memory of many indigenous peoples are marked by the experience in extraction and for many of them establishing definitive residence in the city means freeing themselves from the entrapment in debt and the brutal subordination to the patrão. This subordination is more brutal when the piaçabeiros live close to the piaçabais, a situation when the families dedicate themselves exclusively to this activity and are totally dependent on the merchandise acquired through debt for their survival and the reproduction of their domestic group. When the fregueses live in communities or in the city, the room for maneuver and negotiation is broader, because the relations of subordination based on personal dependence are more flexible; which does not eliminate tensions, conflicts and accentuated asymmetries.

The constant mobility of the reproduction strategies of the domestic groups should be highlighted, as well as the alternative economic activities and the search for autonomy whose expression is the establishment of residence in a community of residents, the belonging to which is socially recognized by establishing "uma rocinha" (a small plot for farming). Expressions that are recurrent in the accounts of the indigenous about the formation of communities such as, "it was all cerrado" (dense vegetation), it "was all mato" (jungle), "it was very ugly", form the basis of ethical and aesthetic judgments that contrast to the expression "making community" as social production of an inhabitable place in the middle of the forest, that is, the result of a political and moral economy of kinship that involves memory, religion, family trajectories and socio-environmental knowledge. Together with the home, they constitute the symbolic elements of filiation to a community; which does not exclude the possibility of having a home in another place like the city of Barcelos or Santa Isabel - multi-localization. There is an interlinking between the production of kinship and of community - the community makes the relatives and the relatives make community - with the choices of economic alternatives emphasized in a given moment of the reproductive cycle of the domestic group.

School education is one of the main pillars in the formation of the community and its forms of sociability. A school unit has central importance not only to the formation of communities, but also in internal disputes and relations with outside agencies. School and chapel (Catholic or Evangelical) are two pillars in the formation of the communities, of the process and dynamics of social organization and of habitable space in the forest that incorporate a model of sociability or good society based on kinship and neighborliness. The chapel or house of worship is a foundation for good sociability (good conviviality among relatives, kin and neighbors) inherent to the ideal of a prosperous community. The festival of the

41 See note 18 . 
patron saint and the chapel are indicators of the importance of the religious sphere for the community sociability and for the knowledge of traditional indigenous occupation on the Middle Rio Negro. There is an hierarchical tie established between the saint, the oldest family nucleus and the community, which is fundamental to guaranteeing prosperity and good sociability among relatives, kin and neighboors, or that is, of "making community". The festivals maintain intra- and inter-community ties, and articulate the sacred and the profane in a privileged form of public and symbolic manifestation of the community. They stimulate and concentrate economic exchanges and ritual interchanges that encompass ties among relatives and kin dispersed through the various communities as well as relatives in the cities of Barcelos and Santa Isabel do Rio Negro.

The formation of indigenous communities in the Middle Rio Negro, therefore, is directly linked to the use and handling of geographically dispersed basic natural resources that are strategic to social reproduction. The communities are population nuclei formed by various domestic groups. ${ }^{42}$ There is a strong sense of collective belonging, subjacent to memories of biographic and family paths through the social networks of aviamento, the identification with the protective spiritual forces (Catholic patron saints, pajés, rezadores and benzedores) and the desire for autonomy from the boss. Therefore, good sociability and "making community" also involve relations with dangerous supra-human entities, which can cause disease or death (encantados, curupiras, maquiritares, matis, mapinguari, matinta-pereira, cobra-grande) ${ }^{43}$ the control of which also relates to appropriate or prohibited uses of natural resources. The disappearance of people is attributed to encantados (spells) that lead them to their city or to the bichos (bewitched animals) that transform the people into animals. ${ }^{44}$ The categories of mediators of this relationship (whose limits are flexible) are the pajés, rezadores, benzedores and sacacas who correspond to different practices of cure, and distinct supra-human powers and abilities, as well as the various modalities and instruments of acquisition and conservation of abilities of interlocution with these figures of alterity (Peres 2013: 288-294). There are sacred places (mountains and lakes) where the access to and use of natural resources is possible only when accompanied by ritual procedures that suspend an interdiction and guarantee protection. There are times when bathing in rivers should be avoided, because encantados can attack, causing illness in someone who does not respect certain rules of conviviality, domestication (pacification) of the bichos da mata, do fundo and do mundo de cima (bewitched creatures of the forest, waters and sky). The "baptism of water", for example, protects the child who is vulnerable to these bichos or visagens or assombramentos (which are interchangeable categories), when she acquires a godfather who will be respected even after a Catholic baptism, when she gets another godfather (Peres \& Nascimento 2016: 303-306). It should be highlighted that around these categories of pathogenic and dangerous agents, representations are articulated about the past and present that are at the foundation of experiences and interpretations about the social changes experienced (Peres 2013: 270-288).

The communities are social configurations characterized by personal ties of kinship, affinity and neighborhood in which is established a moral universe that defines the collective norms of access to natural resources and to the flexible limits of territorial rights in relation to other communities and social groups.

\footnotetext{
42 The number of domestic groups may be from a few to dozen, as in the case of large communities like Piloto or Cumaru on the right bank of the Rio Negro.

43 Types of spells that take the form of animals or hybrid beings, partly human and partly animal.

44 Encantado can relate to a category encompassing all the bichos, visagens or assombramentos (apparitions) or can define a specific modality of threatening super-human agency. In the later case, the encantados are vengeful beings that are angry with humans (according to a Tariana version), because they were not able to be transformed into people when the first ancestors (fish) left the snake-canoe and originated the indigenous peoples of the Rio Negro. The encantados live in invisible cities, located at the bottom of rivers or in environments that are seen by humans as forests; they are relatives (ancestors) of the whites, because they are also beings characterized by the absence of ethnic or tribal attributes. In the world of the encantados they understand that they are people and the humans are seen as animals and they appear to humans as animals here in our world (Peres 2013: 295-300).
} 
They are founded on a central tripod composed of the social center, chapel and school. They are doted with a scheme of positions of formal authority represented in the positions of president or administrator, teacher or healthcare agent.

The roça (small plantings) is a materialization of the kinship relations and of territorial rights. It has a multiple dimension, with a quite complex signification. The home is also important as an icon of domestic life and social reproduction of the family group, which delineates the local physical space of the community in differentiated segments of appropriation and common and private use - the quintais (yards). The flour house or oven (as well as the number of roças - small plantings) is also a relevant icon of social position of the families, because it expresses collective projects of permanence and identity ties with the community as a unit of social conviviality and not only as a restricted space of residence or even of use of certain public services, such as schooling for small children.

\section{Scheme of a community located on the Demeni River.}

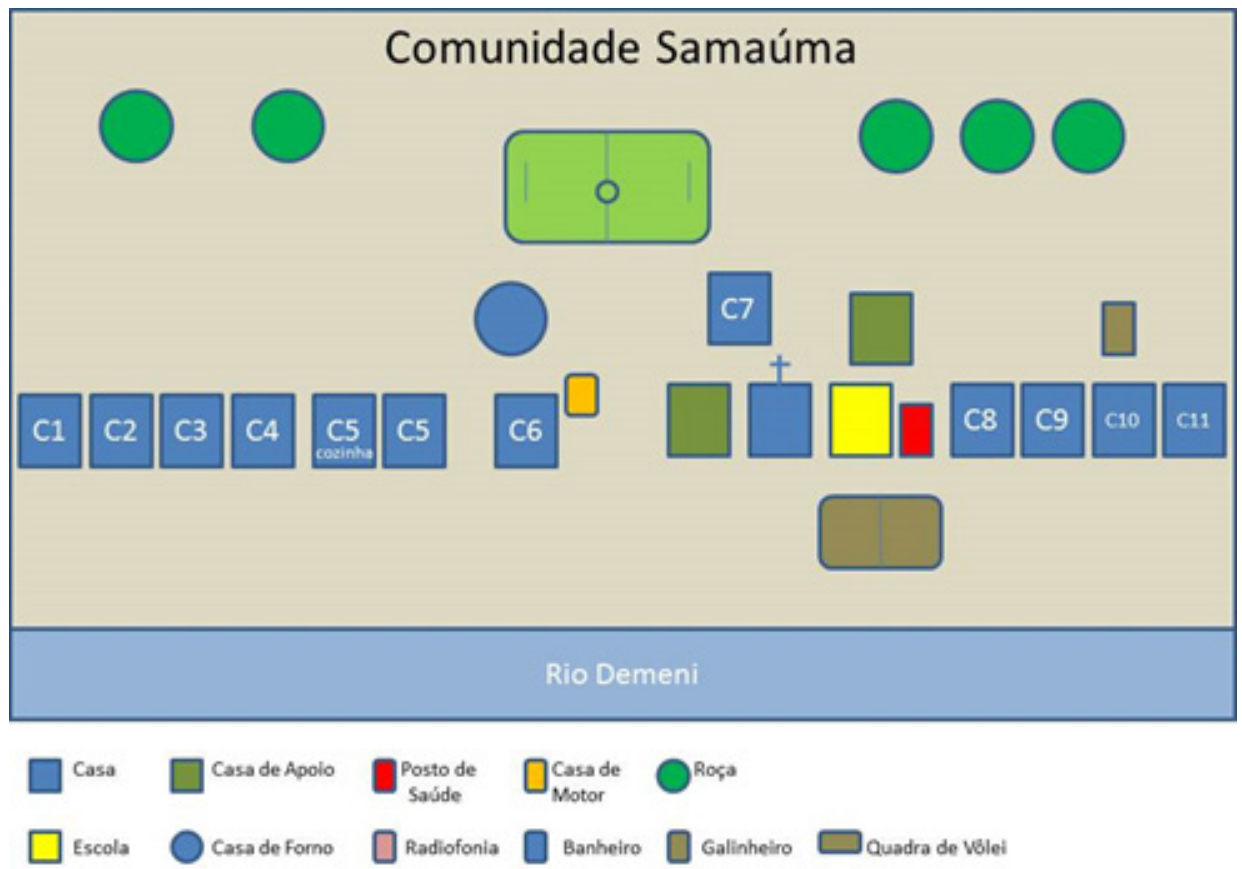

Home, support building, health clinic, Shack for motors, garden School, Oven house, Radio station, Bathroom, Chicken coop, Volleyball court.

The indigenous groups are organized in a community in Rio Negro, which is a social formation that has its historicity and singularity not linked to any notion of static, genuine and immemorial culture. The formation of ethnic associations is organized on a territorial basis, using as a reference groups of indigenous communities that inhabit stretches of rivers or even entire river basins. This network of organizations can encompass river basins, such as the Association of the Indigenous Communities of the Rios Padauiri and Preto and the Association of Indigenous Communities of the Aracá and Demeni Basin (ACIRPP and ACIBAD);45 a municipality, such as Indigenous Association of the Middle Rio Negro (ASIBA); a microregion, such as the Indigenous Association of the Middle Rio Negro (ACIMRN) ${ }^{46}$ and a region, the Federation of Indigenous Organizations of the Rio Negro (FOIRN), linking them to other regional networks; 
such as the Coordination of the Indigenous of the Brazilian Amazon (COIAB) ${ }^{47}$ or transnational; such as the Coordinating Committee of the Organization of the Amazonic Cuenca (COICA) networks, ${ }^{48}$ in an hierarchical model of coordination that is more or less centralized, but whose units have relative autonomy. The formation of associations in the region is a model of organization and social and political expression of ethnicity that is transmit and redefined according to singular situations of conflict and interlocution with allies and antagonists (active through local, regional, national and global agendas).

This social field, described in general lines, expands the horizon of intelligibility of the process of indigenous emergence of the "caboclos of Barcelos". This situation is necessary, but not sufficient, because it should be completed with the delimitation of the political context in which ethnicity is objectified in an indigenous association, in which the entrance of new actors and standards of interaction introduce sharp social transformations in the configuration of interethnic relations and in the conditions for social production of the conflicts involving the promotion of specific territorial rights.

\section{Formation of associations, ethnicity and the emergence of the "Indians of Barcelos"}

The rise of the Associação Indígena de Barcelos/ASIBA [Indigenous Association of Barcelos] is inserted in a larger movement of recapturing of ethnic identity, the formation of indigenous associations and the conquest of territorial rights on the Rio Negro, but has some specific characteristics. On the Upper and Middle Rio Negro, the indigenous movement arose in the context of struggles for demarcation of indigenous land and the associations mainly originated in the communities from the interior. On the Lower Rio Negro, the indigenous movement emerged at the heart of demands for better conditions of insertion in the urban social fabric, whether through the commercialization of production of crafts and valorization of cultural goods, or through access to healthcare services; and was developed through a process of ethnic reaffirmation that involved indigenous residents of the city of Barcelos.

The Indigenous Association of Barcelos was created in 1999, at the First Encounter of the Provisory Indigenous Commission, held on November 5 , in the parochial hall of the Nossa Senhora da Conceição church, because of the situation of privation and discrimination of indigenous families that live in the city experience, mainly in the spheres of health, housing, education and income (minimum prices paid for indigenous crafts). In 1999, a survey was conducted of the cultural goods destined for preservation in Barcelos, based on registration and recognition as national patrimony, by a team from the 1st Regional Superintendency of the Naitonal Institute of Historic and Artistic Patrimony/IPHAN, based in Manaus. The Tariana writer and indigenous militant Ismael Moreira, a long-term resident of Manaus, was invited to help establish trust and make viable the work among indigenous residents of Barcelos. He became part of a team from IPHAN that issued questionnaires and coordinated meetings in the houses of 131 indigenous families from Oct. 27 to Nov. 10, 1999, stimulating a latent sense of collective belonging based on public affirmation of their differentiated ethnic origin and common experience of privations and discrimination in that urban Amazon context. Ismael helped to organize the 1st Indigenous Encounter of Barcelos. Two Baré leaders, from the neighborhoods of Aparecida and São Sebastião respectively, had been speaking with Ismael about the possibility of mobilizing the "relatives" and creating an association. They were the main articulators of a survey of the indigenous population of the city proposed by one of the directors of the Federation of Indigenous Organizations of the Rio Negro, Miguel Maia, to support a proposal for expansion of the Special Indigenous Sanitary District of the Rio Negro/DSEI-RN (Peres 2013: 309-365).

47 Coordenação das Organizações Indígenas da Amazônia Brasileira.

48 Coordinadora de las Organizaciones de la Cuenca Amazónica [Coordinating Committee of the Organization of the Amazonic Cuenca]. 
On November 5, 1999, in the parochial hall of the Nossa Senhora da Conceição church, the first large meeting was held with participation of a total of go people of various ethnicities. The local representative of the National Indian Foundation (FUNAI) was present, the priest of the Nossa Senhora da Conceição parish; and the secretary of tourism. That is, three important entities from the structure of municipal power were inserted: the federal and municipal governments and the church. The indigenous assembly established a sphere of dramatization of indigenous power and autonomy in relation to "our authorities" as in a ritual of inversion and domestication of ordinary power relations. Another fact that strongly expressed this idea of the assembly as a space of the Indians, for affirmation of their identity and respect and valorization for the "customs of the ancestors" were the discourses given in the indigenous languages that constructed a public space guided by modes of communication relegated to the domestic domain. Ancestry was a recurring reference in this new scenery of visibility and reformulation of "Indianness".

The moment was marked by strong manifestations of ties to traditions. The main issue raised in the meeting related to the need for the Indians to organize so that they are valued and their culture and identity preserved. Two other recurring categories at this time synthesize the aspirations and expectations generated there: respect and rights. Thus, they demanded the right to be indigenous and respect for their differences. They also affirmed a broader identity through the common experience of life in that small Amazonic urban context, expanding the term of inclusion "relative" to all "Indians of the city". The image of the maloca rose as the architectural symbol of the process of revitalization of the culture of the past. A new meeting was set for Dec. 10 -12 1999.

The 2nd Encounter of the Provisory Indigenous Commission took place on these dates. Some 40 people participated from the following ethnicities: Baré, Baniwa, Tukano, Desana, Piratapuia, Arapaço and Werequena. The meeting had collaboration from representatives of the Federation of Indigenous Organizations of the Rio Negro and the Instituto Socioambiental, the Coordination of the Indigenous of the Brazilian Amazon, and CIMI (the Indigenous Missionary Council). The absence of any representative from the municipality should be highlighted, while representatives of indigenous organizations and support entities did attend. This meeting was less charged by emotional demonstrations of valorization of ancestry and was more oriented to the instrumental aspects of establishing the organization. The discursive space was predominantly occupied by the representatives of the agencies that may be able to assist in establishing more permanent cooperation. The event thus marked the entrance and recognition of the Indigenous Association of Barcelos in the network of the indigenous rights movement in a regional and macro-regional realm. In the same month, indigenous militants from Barcelos were invited to attend a course in leadership training promoted by the Federation of Indigenous Organizations of the Rio Negro at São Gabriel da Cachoeira.

Nevertheless, in the following year, the Indigenous Association of Barcelos established closer ties with communities in the interior when it conducted visits to undertake a census of Barcelos' indigenous population, considering the expansion of the Special Indigenous Sanitary District (DSEI) of the Rio Negro (DSEI/RN). ${ }^{49}$ Representatives of the communities appeared at the II Indigenous Assembly in 2000, taking their demands and denouncing invasions; and mainly complaining of the degrading working conditions in the piaçabais and the arbitrary and violent power of the bosses. In the following year the Indigenous Association of Barcelos made closer ties with the communities, holding small preparatory assemblies to mobilize the III General Assembly in the city of Barcelos. At this time, the representatives of the communities renovated their charges of invasion of their lands by geladores, ${ }^{50}$ sport fishing tourism,

\footnotetext{
49 Promoted by FOIRN/ISA for the expansion of DSEI/RN, which was restricted to the municipality of São Gabriel da Cachoeira.

50 "Gelador" (which literally means freezer) is the local term used to designate commercial fishing boats that operate in the region to obtain large volumes of fish.
} 
arbitrary command of the extractive colocações by the patrões and accentuated exploitation of labor in these locations. They also presented, for the first time in public, the demand for demarcation of indigenous lands. The establishment of organizations thus established a new channel for the collective expression of the desire for autonomy in relation to the patrões (a type of utopian vision) and of control over the basic resources needed for the social reproduction of the communities.

The Indigenous Association of Barcelos then came to count on important partners such as the National Indigenous Foundation/Barcelos, FUNASA/Barcelos, the Fundação Vitória Amazônica/FVA, the National Institute of Historic and Artistic Patrimony (IPHAN), the Catalon NGO Caldes Solidaria, the University of Barcelona, and the Nucleus of Amazon Studies of Catalonia/NEAC. The project for institutional consolidation, supported by Caldes Solidaria, began from an annual plan that some members of the Indigenous Association of Barcelos prepared in 2000 for the Federation of Indigenous Organizations of the Rio Negro to include in its annual planning for 2001. The financial, human and logistic support from the Federation were restricted to electoral assemblies of the associations, which compromised realization of the general assembly of the Indigenous Association of Barcelos. Therefore, the direct capturing of resources from international cooperation showed that the Indigenous Association of Barcelos was tracing a path of relative financial autonomy in relation to the Federation of Indigenous Organizations of the Rio Negro.

An important component of the project for consolidation was the approximation with the communities of the interior and the mobilization for the general assembly of the Indigenous Association of Barcelos. Four mini-assemblies were planned: one in Cumaru, on the Rio Negro up river from Barcelos; one in Tapera, on the Padauiri River; one in Elesbão, on the Aracá river; and another in Carvoeiro, on the Rio Negro down river from Barcelos. The main issues raised were indigenous rights, land, the Special Indigenous Sanitary District/Barcelos and the formation of the local indigenous health council. In the discussion about rights, land and socio-environmental conflicts, the representatives of the Indigenous Association of Barcelos suggested and oriented requests for demarcation of indigenous territory that were presented to the regional administrator of FUNAI/Manaus who was present at the general assembly of 2001.

The consolidation project also consisted in the realization of the general assembly which was held from Oct. $26-28,2001 .^{51}$ At this time, various participants made denouncements and asked what more immediate measures could be taken in response to the invasions from sport fishing tourism, the geladores and the accentuated exploitation by the patrões, while their requests for demarcation of indigenous lands were not attended. This assembly expressed the visibility conquered by the Indigenous Association of Barcelos in the local political situation. The appearance of two municipal secretaries and of the vice-mayor revealed that the indigenous association had become an important and independent interlocutor in the micro-regional correlation of forces.

The assembly was also a condensed demonstration of the new local public sphere constituted by ethnic identity politics, codifying a diffuse perception of privations and injustices in the language of indigenous citizenship. A notable novelty in relation to the previous assemblies was the substantial presence of indigenous leaders from the Amazon, indicating the increased access and visibility of the Indigenous Association of Barcelos in the indigenous movement on the macro-regional level. It demonstrated its capacity to establish partnerships and alliances, thus constituting a solid base of support for its demands. Land - a dominant demand among the residents of the communities, absent in the previous assemblies - came to integrate the agenda of an organization for collective mobilization of ethnicity because of the privations (material and moral) suffered in the urban environment.

51 The indigenous participation was good, varying from 100 to 267 participants, residents of the city and the community, from the following ethnicities: Baré, Baniwa, Tukano, Desana, Werequena, Tariana, Arapaço, Tuyuca, Piratapuia, Lanaua, Canamari, and Apurinã. 
The Catalon NGO Nucli d'estudis per a l'Amazònia de Catalunya - NeAC, was an essential partner of the Indigenous Association of Barcelos, acting as a mediator in Barcelona, Spain for capturing resources for the projects (mainly in the fields of agriculture and apiculture) undertaken together with the indigenous of the city and the interior. The Fundação Vitória Amazônica collaborated with studies and actions aimed at training in indigenous crafts and their commercial viability. Various departments were created (education, agriculture, women, crafts), responsible for the actions in course, and suggested problems common to the process of consolidation of various indigenous organizations in Brazil, linked to project management ${ }^{52}$ and the disproportion between the possibilities for service and the expectations and demands created. These difficulties led to internal conflicts that culminated in a sharp and intense electoral dispute for leadership positions of the association, in which members of the board formed rival slates at the VI General Assembly of 2005.

In late 2006, the Nucleus of Amazon Studies of Catalonia suspended its collaboration and beginning in the following year the Federation of Indigenous Organizations of the Rio Negro and the Instituto Sociambiental began to act with greater regularity together with the Indigenous Association of the Middle Rio Negro and the Indigenous Association of Barcelos. Barcelos thus became a stage of important events on the indigenist and environmental agenda of these agencies for intervention. Emphasis should be given to the Mobilization of Indigenous Peoples of the Middle Rio Negro, realized in July 2009; and the two Seminars about Territorial Order in the Middle Rio Negro, held in November 2008 and October 2009. In this context, four indigenous associations were created: the Indigenous Association of the Aracá and Demeni Basin - AIBAD; the Associação Indígena de Floresta and Padauiri (AIFP) [Indigenous Association of Floresta and Padauiri]; the Associação Indígena da Área de Canafé e Jurubaxi - AIACA [The Indigenous Association of the Area of Canafé and Jurubaxi]; and the Associação Indígena do Baixo Rio Negro e Caurés - AIBRNC [Indigenous Association of the Lower Rio Negro and Caurés]. Nevertheless, the patrões also organized (Peres 2010: 213-232).

The Cooperativa de Piaçabeiros do Médio e Alto Rio Negro (COPIAÇAMARIM) [Cooperative of Piaçabeiros of the Middle and Upper Rio Negro] was created in 2008 to confront any proposal for delimiting territorial demarcation that recognized indigenous rights. This cooperative is led by small patrões, who directly recruit the piaçabeiros and are subordinate to the patrões who occupy privileged positions on the commercial network of piaçava that extends outside the region of the Middle Rio Negro. Together with the Barcelos City Council, COPIAÇAMARIM conducted a strong campaign (including marches, vehicle processions, and on radio, internet and newspapers of Manaus) against the official recognition of indigenous lands in Barcelos. In this context of political mobilization, social conflict and dispute for control of natural resources, in 2007 was created the Cooperativa Mista Agroextrativista dos Povos Tradicionais do Médio Rio Negro (COMAGEPT) [Mixed Agro-extractive Cooperative of the Traditional Peoples of the Rio Negro], which proposed to represent farmers, fishermen (of edible and ornamental fish) and extractive workers, indigenous or not, to promote better conditions for the sale of their products and break with the dependence of the bosses. This organization was not as emphatically opposed to the demarcation of indigenous lands, but postulated the creation of Extractive Reserves. The Colônia de Pescadores Z-33 (COLPESCA Z-33) (a fishemrmen's association), which was created in 2002, also took a position against the demarcation of indigenous lands (Menezes 2014: 44-60).

With the institutional strengthening of the ASIBA, in 2007, the National Indian Foundation (FUNAI) promoted the realization of studies for identification and demarcation of indigenous land in the municipalities of Barcelos and Santa Isabel do Rio Negro, forming two technical groups (GTs). Nevertheless,

52 Like the projects for construction of a Maloca, the Indigenous Urban Park and a warehouse for manufacturing brooms, which were not successful. In the later case, the warehouse was constructed, but became the offices for the Indigenous Association of Barcelos. 
the respective anthropological reports were not approved by the General Coordination of Identification and Delimitation of FUNAI and two new technical groups were formed, in late October 2009, to conduct new anthropological and environmental studies. One of the teams was responsible for the studies of identification on the Jurubaxi and Téa river basins; and another on the Aracá and Demeni river basins, on the left bank of the Rio Negro, also including the area of scope of the Comunidade Canafé, on the right bank..$^{53}$ The Jurubaxi-Téa indigenous land $(1,208,000 h a)$ concluded its process of identification and delimitation with the emission of the Declaration by the Ministry of Justice on Sept. 11, 2017. ${ }^{54}$

\section{Final considerations}

The effect of "Galvão's" culturalist approach, considered at the beginning of this article, is not very different from the current culturalist approaches, which are apparently more sophisticated, because they seek reified alterities, Amerindian ontologies that process the changes (the designated transformations and cosmopolitics) in cultural logics destitute of historicity. The notion of assimilation surreptitiously invades this paradigm in an inverted manner. Historically constituted networks of interdependence, which involve the state and other social actors are reduced or even ignored based on simplifying formulas (replete with facile dichotomies: traditional x modern; cosmological alterity x ethnic identify; authentic x spurious; cultural imperative $\mathrm{x}$ historic contingence) that are used to understand agricultural systems, indigenous bureaucracies, policies for patrimonialization, health and education and social and political construction of territorial rights or even to propose a structural aptitude of certain indigenous groups to the assimilation of the other. Research often becomes merely an opportunity to attest to what is already known, with problems of incongruence with the empiric situation resolved by using the canonic ethnological bibliography to authorize decontextualized interpretations and analyses.

The approach presented here is different. It is inscribed in a proposal of historic anthropology in which processes of territorialization, ethnicity and indigenous activism are understood based on the academic debate about the Amazonic Frontier. Pacheco de Oliveira (2016a) revised this debate, deconstructing the various approaches to the so-called rubber-cycle, proposing two models of rubber production and highlighting some analytical potentialities of the category of frontier. The focus here was directed towards the link between frontier, social reproduction of domestic groups and compulsory modes of mobilization of the labor force. The model of seringal (rubber production) that Pacheco de Oliveira (2016a) calls caboclo is highly pertinent to an ethnography of aviamento the formation of associations by the indigenous and of social production of territorial rights on the Middle Rio Negro, due to the following aspects:

a. In this study I am considering two different productive units and modes of social reproduction that are coexisting and articulated;

b. Community is a mode of social organization that is historically constituted in the context of relations of subordination of the labor force and ecclesiastic tutelage;

c. The domination of the patrão is not supported by expropriation of land or land ownership, but by control of access to sale and financing of the production of extraction;

\footnotetext{
53 These second technical groups conducted studies to identify a broader area including the Quiuini and Caurés river basins, the communities down river from Barcleos at the mouth of the Caurés river. For administrative and budgetary reasons at FUNAI, the identification studies had their area restricted, and it was decided to conclude the report on the left bank of the Rio Negro where the studies were more advanced.

54 The proposal for identification and delimitation was approved by the president of FUNAI and published in the Diário Oficial on 19/04/2016. The anthropological report for identification and delimitation of the Aracá-Demeni Indigenous Land was still being evaluated by the General Coordination for Identification and Delimitation/FUNAI.
} 
d. The close relationship between family trajectories, compulsory labor, market and individual and collective projects of autonomy;

e. (Dis)junction between agriculture and extraction and relations of subordination of the labor force;

f. The limited stock of free land for agriculture (due to ecological and social conditions), geographic dispersion of natural resources, mobility and multiple opportunities for productive activity through access to reserves of natural resources controlled or not by the patrões.

g. The complexity, dynamics and flexibility of the relations of aviamento.

Thus, the categories of "community" and "association" are fundamental to understanding interethnic relations and the expansion of territorial rights on the Middle Rio Negro. "Botar uma roça" (Plant some ground) and the life in community (amid relatives) are the core elements of the recurrent practices and representations of autonomy that permeate the individual and family projects in contrast to "working for the patrão". The establishment of associations created a social context propitious to the inversion of the stigma through the resignification of privileged cultural forms such as language, the pajelança (indigenous healing practices) and the maloca, because the indigenous assemblies became a situation of representation of tradition, memory and identity as symbolic resources for the legitimation of demands for territorial rights and ethnically differentiated public policies. The formation of associations incorporated the community as a basic social unit of ethnic mobilization and political representation. Another important category is "aviamento", the compulsory form of mobilization of the labor force based on debt and confinement that is a counterpart to the community as a form of organization and social reproduction that is sustained by the mobility inherent to the use of geographically dispersed resources and to a sociability based on kinship, affinity and vizinhança.

The expansion of the mosaic of indigenous lands on the Rio Negro is currently concentrated on two river basins, the Padauiri-Preto and the Aracá-Demeni, where there is greater incidence of piaçabais and the indigenous communities have more open conviviality with the domain of the patrões and the repercussions of the aviamento regime. ${ }^{55}$ This region rich in piaçabais is the key element in establishing the conditions of material and symbolic reproduction of the aviamento system.

Received: October 19, 2017

Approved: March 12, 2018

Translation by: Jeff Hoff

\section{References}

CARVALHO, José Porfírio Fontenele de. 1982. Waimiri Atroari: a história que ainda não foi contada. Brasília. Mimeo.

GARFIELD, Seth. 2014. Search of the Amazon: Brazil, the United States, and the nature of a region. Durham: Duke University Press.

GALVÃO, Eduardo. 1979. "Aculturação indígena no rio Negro". In: Encontro de sociedades. Rio de Janeiro: Paz e Terra. pp.135-187.

55 Not only various individuals and families but indigenous communities are also subordinated to the patrões; as in the Padauiri and Preto river basins in which the number and size of the roças (planted grounds) is very limited due to the dependence on time dedicated to extractive activities in the piaçabais. In the Aracá and Demeni river basins there is greater autonomy in relation to the patrões, which is expressed in larger numbers and sizes of the roças. 
HARRIS, Mark. 2010. Rebellion on the Amazon: the Cabanagem, race, and popular culture in the North of Brazil, 1798-1840. Londres: Cambridge University Press.

IBGE. 1957. Enciclopédia dos municípios brasileiros, vol. 1. Rio de Janeiro.

ISA. 1996. “A invasão garimpeira no médio rio Negro”. In: Povos indígenas no Brasil: 1991-1995. São Paulo: Instituto Socioambiental. pp. 146-147.

ISA. 200o. Povos indígenas no Brasil: 1996-200o. São Paulo: Instituto Socioambiental. pp. 267-268.

JACKSON, Jean. 1984. “Traduciones competitivas del evangelio en El Vaupés, Colombia”. América Indígena, 44(1): 49-94.

LEONARDI, Victor. 1999. Os historiadores e os rios: natureza e ruína na Amazônia brasileira. Brasília: Paralelo $15 \mid$ Editora Universidade de Brasília.

MENEZES, Elieyd Souza de. 2014. Os piaçabeiros no médio rio Negro: identidade étnica e conflitos territoriais. Brasília: Paralelo 15.

MONTEIRO, Mário Ypiranga. 200o. A capitania de São José do Rio Negro. Manaus: Editora Valer.

PACHECO de OLIVEIRA, João Pacheco. 2016a. "A conquista do vale amazônico: fronteira, mercado internacional e modalidades de trabalho compulsório". In:O nascimento do Brasil e outros ensaios: pacificação, regime tutelar e formação de alteridades. Rio de Janeiro: Contra Capa. pp. 117-16o. . 2016b. "Uma etnologia dos 'índios misturados'? Situação colonial, territorialização e fluxos culturais". In: O nascimento do Brasil e outros ensaios: "pacificação, regime tutelar e formação de alteridades. Rio de Janeiro: Contra Capa. pp. 193-228.

. 2015. Regime tutelar e faccionalismo: política e religião em uma reserva ticuna. Manaus: UEA Edições. . 1988. "O nosso governo": os Ticuna e o regime tutelar. São Paulo: Marco Zero; Brasília, DF: MCT/CNPq.

PERES, Sidnei \& NASCIMENTO, Luiz Augusto. 2016. Relatório circunstanciado de identificação e delimitação da terra indígena Aracá-Padauiri. Brasília: FUNAI. Mimeo.

PERES, Sidnei. 2008. "A economia moral do extrativismo no médio rio Negro: aviamento, alteridade e relações interétnicas na Amazônia”. Antropolítica: Revista Contemporânea de Antropologia e Ciência Política, 1(2. Sem. 2006): 151-170.

. 2010. "Associativismo, etnicidade indígena e transformações sociais: a manufatura política de direitos territoriais em Barcelos". In: A. W. B. de Almeida \& E. A. Farias Junior (orgs.), Mobilizações étnicas e transformações sociais no rio Negro. Manaus: UEA Edições. pp. 213-232.

. 2013. Política da identidade: associativismo e movimento indígena no rio Negro. Manaus: Editora Valer.

PRANG, Gregory. 2001. "Aviamento and the ornamental fishery of the rio Negro, Brazil: implications for sustentable resource use". In: N. L. Chao; P. Petry; G. L. Prang (eds.), Conservation and management of ornamental fish resources of Rio Negro Basin, Amazônia, Brazil. Manaus: Editora da Universidade do Amazonas. pp. 43-73.

WEINSTEIN, Barbara. 1993. A borracha na Amazônia: expansão e decadência, 1850-1920. São Paulo: Hucitec.

Sidnei Clemente Peres

Federal University Fluminense

Institute of Human Sciences and Philosophy

Department of Sociology

Author's e-mail: sidperes63@gmail.com 